\title{
Jordanian EFL Teachers' Awareness and Incorporation of Multiple Intelligences into Their Pedagogical Practices
}

\author{
Taghrid Ahmad Al-Omari, Ruba Fahmi Bataineh \\ Department of Curriculum and Instruction, Yarmouk University, Irbid, Jordan \\ Email: rubab@yu.edu.jo
}

Received 20 February 2014; revised 22 March 2014; accepted 1 April 2014

Copyright $@ 2014$ by authors and OALib.

This work is licensed under the Creative Commons Attribution International License (CC BY). http://creativecommons.org/licenses/by/4.0/

(c) (i) Open Access

\begin{abstract}
This study attempts to explore EFL teachers' awareness and incorporation of the Multiple Intelligences Theory (MIT) into their pedagogical practices in light of some variables. The sample consisted of 141 male and female EFL teachers who taught the first-, fourth-, eighth- and eleventhgrade Action Pack textbooks in the public schools of the First Directorate of Education (Irbid, Jordan). The findings revealed that, albeit moderate, EFL teachers' awareness and incorporation of MIT is influenced, to various degrees, by gender, grade level, age, qualifications, experience and training.
\end{abstract}

Keywords

EFL, MIT, Multiple Intelligence Theory, Jordan

\section{Introduction}

There is a wide-spread belief that the successful execution of any reform movement depends mainly on teachers [1]. Of all the stakeholders of the educational process, teachers are the ones expected to be the agents of change in their schools in general and classroom in particular. However, there are accounts in the literature which depict the teacher as the single major obstacle to reform, most probably due their beliefs, which, albeit a matter of controversy, are believed to consistently affect teachers' decision making about curriculum and instructional practices (see, for example, [1]-[7]).

Educational literature is rich with calls for teachers to innovate and vary their pedagogical practices to ensure effective learning. To be effectively implemented, innovative pedagogical practices should always be supported by focused, up-to-date pre-service and in-service teacher training [8]. 
The contributions of Gardner's Multiple Intelligence Theory (MIT) to language pedagogy are highly acknowledged [9]-[12]. Ref. [12], for example, identified MIT as the fifth of ten scenarios that may shape the teaching of second languages in this millennium.

MIT has been hailed as the instigator of a significant paradigm shift in education [13]. Educational literature calls on EFL teachers not only to be aware of MIT but also to implement it in their teaching. Ref. [14], for example, encourages educators to consider and develop MIT-based practices for their own contexts according to their best professional judgment.

Even though teachers have always been aware that their students usually varied in their academic abilities, it was the research of [15] that provided directions for capitalizing on student individual intelligences. Per the principles of MIT, a learner-centered philosophy that characterizes human intelligence as having multiple dimensions to be acknowledged and developed through education, the learning process should draw on multisensory channels and encourage learners to experiment with innovative ways of expression [10] [11]. Along the same vein, [16] claims that unless they teach multi-modally and cater for various intelligence types in each lesson, teachers may fail to reach all their learners no matter what approach they adopt.

Acknowledging that the teacher is the key to any sustainable innovation in practice [17], one has to keep in mind that any sustainable reform can only be successful if teachers' beliefs, prior knowledge and attitudes are seriously taken into account in that reform [18] [19] and then developed step-by-step through experience-based learning and reflection [20].

\section{Problem, Purpose, Questions, and Significance of the Study}

MIT has been gaining importance in EFL classrooms around the world. However, this gain in momentum has not been matched by supplementation of textbook content. In other words, even though textbook writers have been apt to respond to the changes in foreign language teaching through combinations of methods and approaches, the text books often remained lacking and in grave need for supplementation. Ref. [16], believed to be the first to incorporate the principles of MIT into language teaching, devotes a chapter in his book, A Multiple Intelligences Road to ELT Classroom, to a variety of exercises, activities and tasks to cater for each type of intelligence. To the researchers' best knowledge, Jordanian EFL teachers' awareness and incorporation of MIT practices into the language classroom have never been researched.

The purpose of this study is to explore EFL teachers' awareness and incorporation of MIT practices into the language classroom. More specifically, the authors seek answers to the following questions:

1) What is the extent of Jordanian EFL teachers' awareness of MIT principles?

2) What is the extent of the incorporation, if any, of MIT into Jordanian EFL teachers' instructional practice?

3) What is the extent of the incorporation, if any, of MIT into Action Pack textbooks?

4) Are there significant relationships (at $\alpha \leq 0.05$ ) between the teachers' awareness and incorporation of MIT practices into the language classroom due to gender, age, grade level, qualifications, experience and training?

The findings are potentially significant for EFL teachers since they are the principal beneficiaries of these findings, especially in light of reports that students vary in their intelligence profiles and, thus, need to have different activities and tasks to ensure optimal learning.

\section{Previous Literature}

Although Gardner's theory was not originally designed for use in the classroom, it has been widely embraced by educators (see, for example, [21] [22]. The application of the idea of MIT has enjoyed numerous adaptations in a variety of educational settings even though it was originally intended for psychologists [14]. However, even though [15] briefly points out the educational implications of MIT, he had little to say about its classroom application [23]. In fact, [24] himself initially admits that he did not pay much attention to the implications of his theory for educators but later amends by discussing the educational implications of the theory:

Yet, given the mission of the Van Leer Foundation, it was clear that I needed to say something about the educational implications of MI theory. So, I surveyed the literature on education and in the concluding chapters touched on some educational implications of the theory. This decision turned out to be another crucial point because it was educators, rather than psychologists, who found the theory of most interest ([15], p. xv).

Nevertheless, even though it was intended for an audience of psychologists and did not have much to say about classroom application, MIT generated a lot of interest among educators who were drawn by its affinity to 
pedagogy and approaches such as whole language and cooperative learning, not to mention its potential to make educators question their work and look beyond the narrow confines of the dominant discourses of skilling, curriculum, and testing [25] [26].

Gardner, who was reportedly amazed by the number of individuals who wanted to revise their educational practices in the light of MIT [27], maintains that it is imperative that teachers take individual differences among learners seriously. However, [28] are quick to point out that teachers do not need to create nine different lesson plans to accommodate all intelligences but rather design rich learning experiences to nurture each learner's combination of intelligences. This is further corroborated by Refs. [16] and [29] who consider it impractical to plan individual lessons for everyone in favor of including materials that cater for all intelligences in every lesson.

To this effect, [13] points out how remarkable it is for MIT to provide a minimum of eight potential pathways to learning, which is, no doubt, a catalyst for effective learning. MIT allows teachers to be conscious not only of their own instructional strategies but also of their students' distinct abilities. MIT posits that students would learn better when teachers use different methods, exercises and activities to reach all students—not only those who excel at linguistic and/or logical intelligence.

Ref. [15] argues that multiple intelligences can be either nurtured or weakened, and that each intelligence can be developed, in various degrees, through instruction. The utility of MIT has been addressed in teaching English as a foreign language (TEFL), as [16] is believed to be the first to apply MIT to language teaching. He outlines MIT and illustrates a variety of challenging exercises for promoting various intelligence types in the EFL classroom.

Ref. [30] maintains that MIT is more a way to understand intelligence than a prescribed teaching method. Teachers can use MIT as a guide for developing classroom activities that address multiple ways of learning and allow choices for achieving and demonstrating learning.

Similarly, Ref. [15] warns against setting MIT as an educational goal in itself, as it should be seen as a catalyst for one's own educational goals. For example, if one's educational goals encompass disciplinary understanding, mobilizing several intelligences would help achieve that goal. (Ref. [30], p. 1) posit that instead of "functioning as a prescribed teaching method, curriculum, or technique, MI theory provides a way of understanding intelligence, which teachers can use as a guide for developing classroom activities that address multiple ways of learning and knowing.” Moreover, MIT potentially promotes learner-centeredness by partially transferring control from the teacher to the learner who chooses how he/she learns and demonstrates his/her learning.

In MI-based language teaching, ([22], p. 118) address the issue that there are neither "goals stated for MIT instruction in linguistic terms" nor a prescribed or recommended syllabus. However, scholars (see, for example, [16]) have proposed ways for using it—not as a prescriptive pedagogical formula but rather as a framework in which teachers engage in exploratory trial and error reform. The language classroom is seen as a setting for educational support systems that empower the language learner to take charge of his/her own learning.

Ref. [31] put MIT into practice as an alternative to traditional classroom design, as do ([28], p. 23) who present MIT as a viable means to overcome some educational problems:

Think of LEGO building blocks. If we have only one kind of block to play with, we can build only a limited range of structures. If we have a number of different block shapes that can interconnect to create a variety of patterns and structures, we can accomplish more nuanced and complex designs. The eight or nine intelligences work the same way.

In their study of EFL teachers' use of MIT-based materials and activities in Turkish primary schools, [32] reported that MIT is used moderately, albeit in an imbalanced manner. No significant differences were observed for gender, program of graduation and seniority although type of school was found to make a significant difference in favor of private schools.

In her study of Brazilian and International EFL/ESL teachers' perceptions about MIT, [33] reported that while 86 percent of her subjects knew MIT, about 90 percent used it in their teaching (albeit about 41 percent do so unconsciously.

\section{Method and Procedures}

This research is essentially quantitative. The sample of the study consisted of 57 male and 84 female EFL teachers who teach Action Pack for the first-, fourth-, eighth-, and eleventh-grades in the public schools of Irbid First Directorate of Education. These grades were chosen because each represents a mile stone in the child's school- 
ing, except for the eleventh-grade which was substituted for the twelfth-grade whose students are never available for research on account of their preparation for the National High School Exit examination.

The distribution of the sample according to the variables of gender, grade level, age, qualification, experience and training is presented in Table 1.

A two-part eight-item questionnaire, the first part of which collected demographic information about gender, grade level, age, qualifications, teaching experiences, and training, was used. Seven items were adapted from Ref. [33]'s 15-item questionnaire to measure the teachers' actual knowledge of MIT while an eighth item was added to identify the participants' awareness of MIT.

To conduct the study, consent was obtained from Irbid First Directorate of Education, the schools and the participants themselves. The questionnaire was then distributed and collected hand-to-hand by the first researcher. The return rate of the filled-in questionnaires was a little over 99 percent (All questionnaires were returned except one).

\section{Findings and Discussion}

To answer the first research question, which seeks to identify the extent of Jordanian EFL teachers' awareness of the principles of MIT, the teachers' responses were analyzed and frequencies and percentages calculated, as shown in Table 2.

Table 2 shows that only 48 (34 percent) of the teachers gave affirmative answers, reporting having heard about MIT from the various sources outlined in the questionnaire. The table also shows that the respondents, who were allowed to pick more than one answer to the question, got their knowledge from various sources, top amongst which are books (54 percent), workshops (50 percent), courses (29 percent) and co-workers or friends (17 percent), respectively. It is a bit disheartening that only one third of the teachers reported hearing about MIT which had emerged in the early 1980's. The Ministry of Education (MoE) is partly responsible for this since its regularly-held workshops have not addressed MIT as a recent pedagogical trend in teaching languages and other subject matters.

\begin{tabular}{cccc}
\hline Table 1. Sample distribution. & & & \\
\hline Independent Variables & Levels & Frequency & Percentage \\
\hline \multirow{2}{*}{ Gender } & Male & 57 & 40.4 \\
& Female & 84 & 59.6 \\
Grade Level & First & 21 & 14.9 \\
& Fourth & 45 & 31.9 \\
& Eighth & 33 & 23.4 \\
Age (in years) & Eleventh & 42 & 29.8 \\
& Under 30 & 12 & 8.5 \\
Qualifications & 30 - 40 & 47 & 33.3 \\
& Over 40 & 82 & 58.2 \\
& Two-year diploma & 11 & 7.8 \\
& B.A. & 101 & 71.6 \\
Teaching Experience (in years) & M.A. \& Doctorate & 29 & 20.6 \\
& Up to 5 & 14 & 9.9 \\
& 6 - 15 & 53 & 37.6 \\
& Over 15 years & 74 & 52.5 \\
Participation in Training Programs & Yes & 115 & 81.6 \\
& No & 26 & 18.4 \\
\hline
\end{tabular}


Table 2 further shows that over 23 percent of the respondents report having researched MIT compared to 73 percent who report wanting to know more about it. This is hardly surprising in light of previous reports that Jordanian teachers are often too overwhelmed by excessive teaching loads to do research. For these teachers, research is more a luxury than a necessity, and those who report having researched MIT may have done that as a requirement for a course or workshop in either pre- or in-service teacher training.

However, that more than two thirds of the respondents expressed willingness to know more about MIT is encouraging in the sense that it indicates potential readiness to learn more about teaching-related innovations. It is evident that teachers should not rely solely on MoE-held workshops but rather seek up-to-date information from other readily accessible sources such as webinars and other Internet resources.

To answer the second research question, which addresses the respondent's self-reported incorporation of MIT in their instruction, frequencies and percentages were calculated not only for whether or not the respondents reportedly use MIT in their teaching but also for the specific types of materials and activities they use, the former of which is addressed in Table 3 below.

Table 3 shows that a little under 28 percent of the respondents reportedly use MIT in their instruction albeit infrequently judging by the low percentage of those who use it very often. These teachers should not be expected to use what they do not know in their instruction, which further points to the need for MoE awarenessraising initiatives to keep these teachers abreast of pedagogical innovations and viable practices.

Table 4 presents the results of the analysis of teachers' responses concerning the types of materials and activities they incorporate in their instruction.

Table 4 shows that only 32 (64 percent) of these types of materials and activities are used by more than 50 percent of the respondents whereas activities, such as field trips, playing musical instruments, slides, statistics and jogging, are used by less than 25 percent of these respondents.

The findings of the sixth item of the questionnaire, which addresses the types of materials and activities implemented by the teachers in their instruction, reveal that a large number of these activities are reportedly used

Table 2. Frequencies and percentages of teachers’ responses about their awareness of MIT.

\begin{tabular}{|c|c|c|c|}
\hline Question & Alternatives & Frequency & Percentage \\
\hline \multirow{3}{*}{ Have you ever heard about MIT? } & No & 40 & 28.4 \\
\hline & Yes & 48 & 34.0 \\
\hline & Not sure & 53 & 37.6 \\
\hline \multirow{4}{*}{ If yes, how did you learn about it? } & Book & 26 & 54.2 \\
\hline & Course & 14 & 29.2 \\
\hline & Workshop & 24 & 50.0 \\
\hline & Learning from coworkers/friends & 8 & 16.7 \\
\hline \multirow{2}{*}{$\begin{array}{l}\text { Have you ever researched } \\
\text { about MIT? }\end{array}$} & No & 108 & 76.6 \\
\hline & Yes & 33 & 23.4 \\
\hline \multirow{3}{*}{$\begin{array}{l}\text { Would you like to know } \\
\text { more about MIT? }\end{array}$} & No & 22 & 15.6 \\
\hline & Yes & 103 & 73.0 \\
\hline & Not sure & 16 & 11.3 \\
\hline
\end{tabular}

Table 3. Frequencies and percentages of teachers' responses about their use of MIT.

\begin{tabular}{|c|c|c|c|}
\hline Question & Alternatives & Frequency & Percentage \\
\hline \multirow{3}{*}{ Do you use MIT in your teaching? } & No & 31 & 22.0 \\
\hline & Yes & 39 & 27.7 \\
\hline & Not sure & 71 & 50.4 \\
\hline
\end{tabular}


Table 4. Frequencies and percentages of the types of teaching materials and activities.

\begin{tabular}{|c|c|c|c|}
\hline No. & Materials and Activities & Frequency & Percentage \\
\hline 1 & Reading & 138 & 97.9 \\
\hline 2 & Writing & 136 & 96.5 \\
\hline 3 & Pair work & 132 & 93.6 \\
\hline 4 & Speaking & 131 & 92.9 \\
\hline 5 & Group work & 129 & 91.5 \\
\hline 6 & Listening & 126 & 89.4 \\
\hline 7 & Cooperative learning activities & 125 & 88.7 \\
\hline 8 & Role plays & 116 & 82.3 \\
\hline 9 & Options for homework & 110 & 78.0 \\
\hline 10 & Moving around the class & 109 & 77.3 \\
\hline 11 & Drawing & 105 & 74.5 \\
\hline 12 & Body language & 104 & 73.8 \\
\hline 13 & Categorizing items (animals, adjectives, nouns, etc.) & 103 & 73.0 \\
\hline 14 & Group problem solving & 103 & 73.0 \\
\hline 15 & Songs/video clips & 100 & 70.9 \\
\hline 16 & Story telling & 99 & 70.2 \\
\hline 17 & Coloring & 96 & 68.1 \\
\hline 18 & Talking about environmental issues & 94 & 66.7 \\
\hline 19 & Note-taking & 91 & 64.5 \\
\hline 20 & Providing materials related to the natural world & 90 & 63.8 \\
\hline 21 & Visual aids (flashcards, pictures, wall charts, etc.) & 87 & 61.7 \\
\hline 22 & Hands-on activities & 81 & 57.4 \\
\hline 23 & Individualized projects & 80 & 56.7 \\
\hline 24 & Singing & 80 & 56.7 \\
\hline 25 & Logic puzzles and games & 79 & 56.0 \\
\hline 26 & Talking about mankind and related issues & 78 & 55.3 \\
\hline 27 & Crossword puzzles & 78 & 55.3 \\
\hline 28 & Group brainstorming & 77 & 54.6 \\
\hline 29 & Maps & 76 & 53.9 \\
\hline 30 & Board games & 74 & 52.5 \\
\hline 31 & Activities with a self-evaluation component & 74 & 52.5 \\
\hline 32 & Classifying and categorizing activities & 74 & 52.5 \\
\hline
\end{tabular}




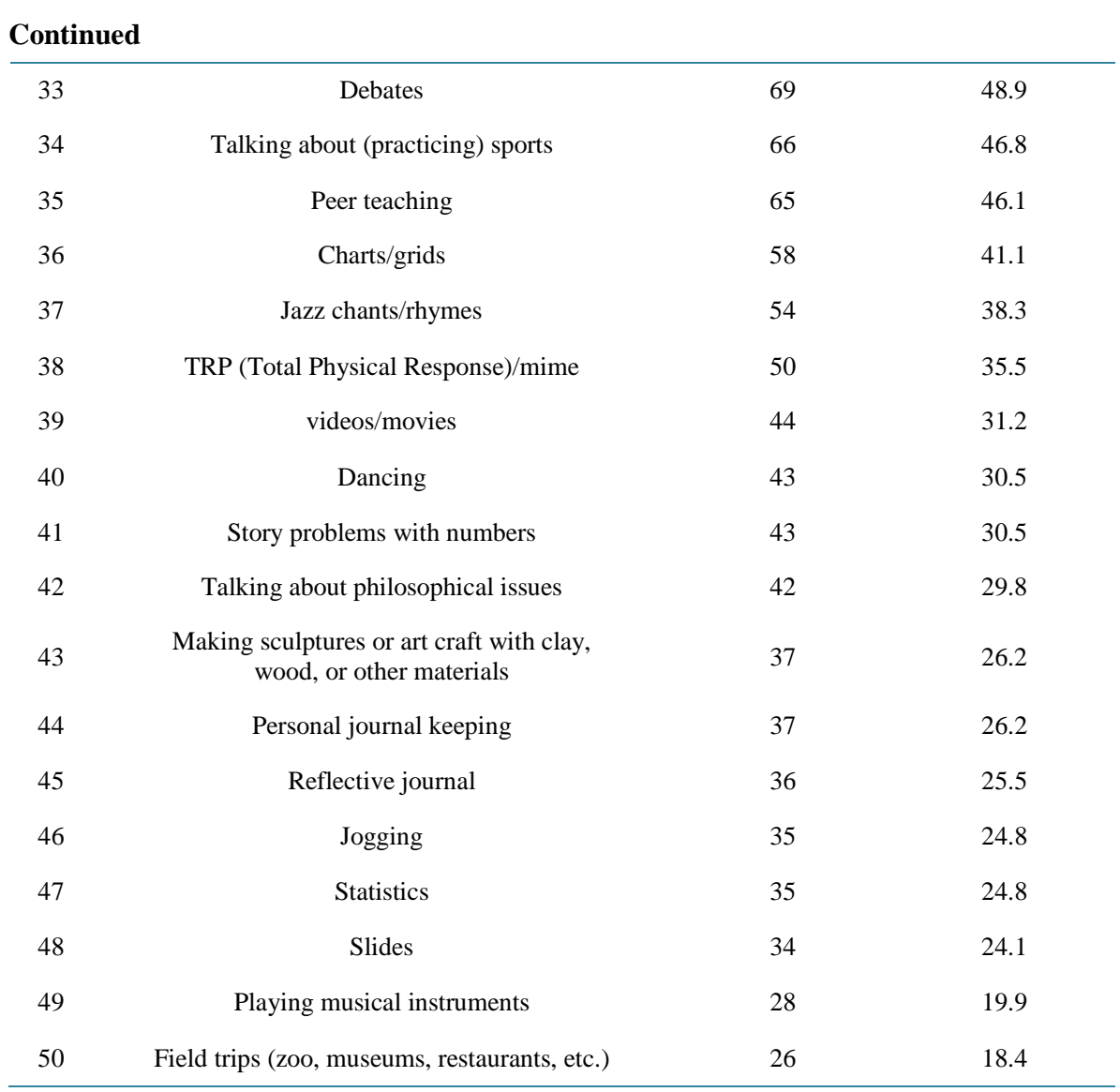

by teachers. Using various modalities for achieving goals is not only necessary but also consistent with calls by the MoE for "variety of instructional strategies: selecting appropriate instructional strategies and methods to insure that all students achieve learning goals" ([34], p. 5).

The authors claim that the use of these materials and activities is more incidental than necessarily MIT-based. This use is most probably CLT-based as, for example, reading, writing, speaking and listening activities are emphasized since the General Guidelines and General and Specific Outlooks for the English Language [34] stipulates that students should show mastery over the four language skills.

Table 5 presents the results of the third research question, which pertains to the anal teachers' responses to the question of whether or not Action Pack textbooks incorporate the principles of MIT.

Table 5 shows that the respondent were divided on this issue, with 44 percent reporting that Action Pack textbooks incorporate MIT in their activities as opposed to a sweeping 56 percent holding the opposite view. This may be readily explained in light of reports that a lot of these teachers have not heard about MIT and, thus, their ability to judge whether or not MIT principles are in the textbook series is crippled by their lack of knowledge.

The fourth research question addresses whether or not significant relationships (at $\alpha=0.05$ ) exist between gender, grade level, age, qualification, experience and training and the teachers' knowledge of and perceptions about MIT, as discussed below.

\subsection{Gender and Teachers' Perceived Knowledge and Incorporation of MIT}

Table 6 presents the results of the association analysis between gender and teachers' perceived knowledge and incorporation of MIT.

Table 6 shows that more male teachers reported having heard about and used MIT than their female counterparts. However, female teachers reportedly use group problem solving, pair work, songs/video clips, role plays, board games, TPR/mime, cooperative learning activities, field trips (zoo, museums, restaurants, etc.), videos/ 
Table 5. Frequencies and percentages of teachers' responses about their incorporation of MIT in action pack textbooks.

\begin{tabular}{ccc}
\hline MIT Incorporation & Frequency & Percentage \\
\hline No & 79 & 56.0 \\
Yes & 62 & 44.0 \\
\hline
\end{tabular}

Table 6. $\chi^{2}$ test of independence regarding gender.

\begin{tabular}{|c|c|c|c|}
\hline Gender Crossing Question & $\begin{array}{c}\chi^{2} \text { Tests } \\
\text { Value }\end{array}$ & $D_{f}$ & Sig. \\
\hline Have you ever heard about Multiple Intelligences Theory (MIT)? & 21.728 & 2 & 0.000 \\
\hline Have you ever researched about MIT? & 3.567 & 1 & 0.059 \\
\hline Would you like to know more about MIT? & 1.980 & 2 & 0.372 \\
\hline Do you think you use MIT in your teaching? & 6.794 & 2 & 0.033 \\
\hline Categorizing items (animals, adjectives, nouns, etc.) & 3.218 & 1 & 0.073 \\
\hline Reflective journal & 3.063 & 1 & 0.080 \\
\hline Group problem solving & 6.592 & 1 & 0.010 \\
\hline Pair work & 14.167 & 1 & 0.000 \\
\hline Songs/video clips & 38.526 & 1 & 0.000 \\
\hline Role plays & 12.579 & 1 & 0.000 \\
\hline Board games & 22.864 & 1 & 0.000 \\
\hline Total Physical Response (TPR)/mime & 8.679 & 1 & 0.003 \\
\hline Cooperative learning activities & 8.958 & 1 & 0.003 \\
\hline Field trips (zoo, museums, restaurants, etc.) & 3.984 & 1 & 0.046 \\
\hline Debates & 0.094 & 1 & 0.759 \\
\hline Videos/movies & 10.592 & 1 & 0.001 \\
\hline Individualized projects & 2.260 & 1 & 0.133 \\
\hline Note-taking & 2.284 & 1 & 0.131 \\
\hline Drawing & 28.006 & 1 & 0.000 \\
\hline Listening & 24.737 & 1 & 0.000 \\
\hline Playing musical/Rhythmic instruments & 12.806 & 1 & 0.000 \\
\hline Making sculptures or art craft with clay, wood or other materials & 21.754 & 1 & 0.000 \\
\hline Reading & 4.517 & 1 & 0.034 \\
\hline Maps & 1.643 & 1 & 0.200 \\
\hline
\end{tabular}




\section{Continued}

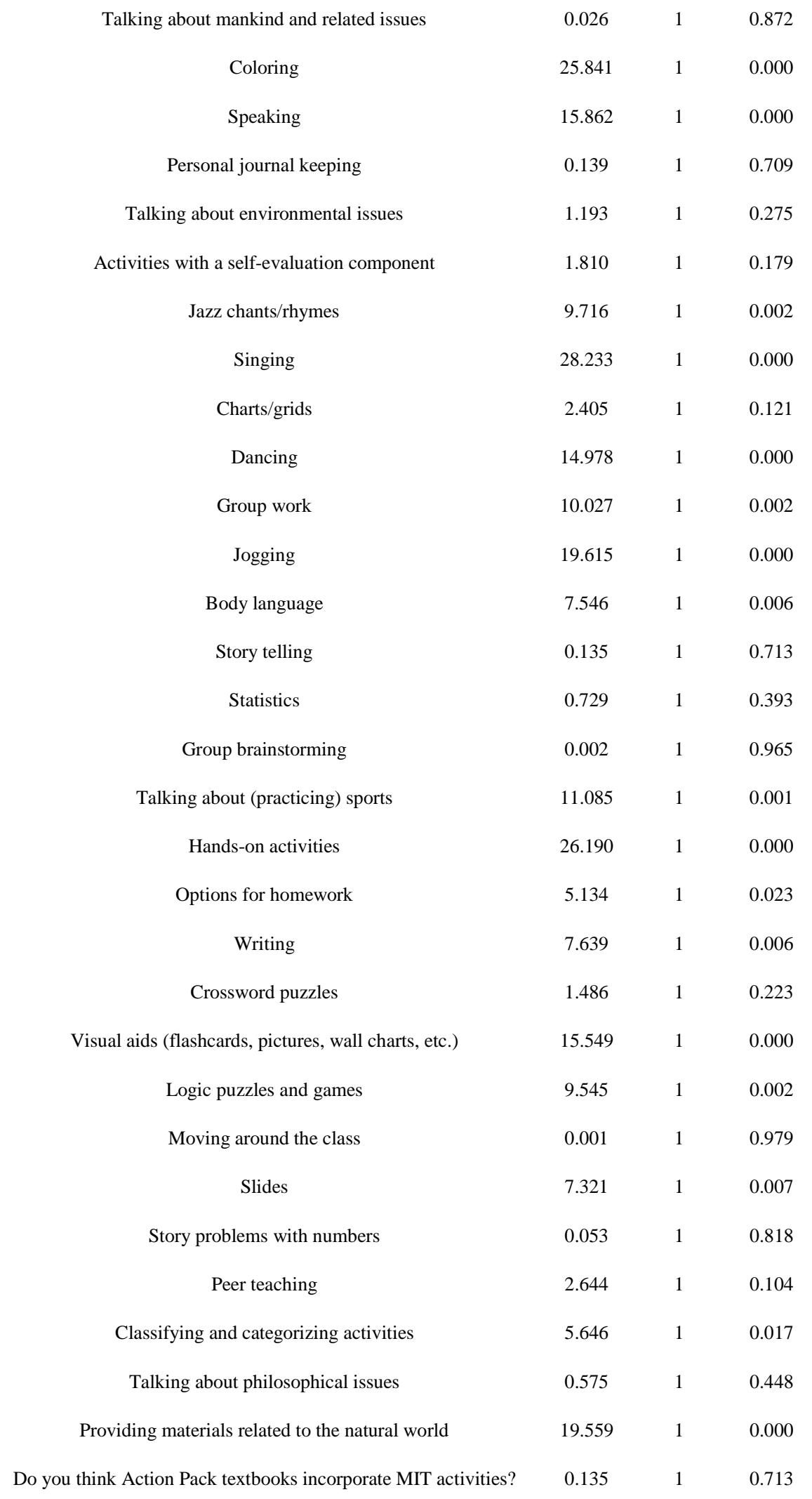


movies, drawing, listening, playing musical/rhythmic instruments, making sculptures or art craft with clay, wood, or other materials, reading, coloring, speaking, jazz chants/rhymes, singing, dancing, group work, jogging, body language, talking about (practicing) sports, hands-on activities, options for homework, writing, visual aids (flashcards, pictures, wall charts, etc.), logic puzzles and games, slides, classifying and categorizing activities and providing materials related to the natural world than their male counterparts across the grade levels.

Both male and female teachers reportedly believe that the Action Pack textbooks incorporate MIT in their activities, since no significant association was found between gender and the incorporation of MIT in their teaching.

\subsection{Grade Level and Teachers' Perceived Knowledge and Incorporation of MIT}

Table 7 presents the results of the association analysis between grade(s) taught and teachers' perceived knowledge and incorporation of MIT.

Table 7 shows that more eleventh-grade teachers reported hearing about MIT than their first-, fourth- and eighth-grade counterparts while more fourth-grade teachers reported having heard about MIT than their firstand eighth-grade counterparts. Meanwhile, more eighth-grade teachers reported having heard about MIT than their first-grade counterparts.

Reflective journals, statistics, group brainstorming and talking about (practicing) sports were more used by eleventh- than eighth-, first-, and fourth-grade teachers, respectively, while pair work, songs/video clips, drawing, listening, making sculptures or art craft with clay wood or other materials, coloring, jazz chants/rhymes, singing, group work and writing were reportedly more used by first-grade teachers than their fourth-, eighth- and eleventh-grade counterparts, respectively.

On the other hand, playing musical instruments, dancing, jogging and logic puzzles and games were reportedly more used by first-grade teachers than their eighth-, fourth- and eleventh-grade counterparts, respectively while debates and slides were reportedly used by eleventh-grade teachers more than their first-, eighth- and fourth-grade counterparts, respectively. By the same token, individualized projects and storytelling activities were reportedly used more by eighth-grade teachers than their eleventh-, first- and fourth-grade counterparts, respectively.

Role play activities were reportedly used more by fourth-grade teachers than by their first-grade counterparts, while crossword puzzles were reportedly more used by eighth-grade teachers than their first-, fourth- and eleventh-grade counterparts, respectively. Similarly, peer teaching was reportedly more used by eleventh-grade teachers than their fourth-, eighth- and first-grade counterparts, respectively, while talking about environmental issues was reportedly used more by eleventh-grade teachers than their eighth-, fourth- and first-grade counterparts, respectively. Finally, hands-on activities were reportedly used most by first-grade teachers, more so than their eighth-, eleventh- and fourth-grade counterparts, respectively.

Teachers across the four grades reported that Action Pack textbooks incorporate MIT in their activities, since no significant association was found between the grade(s) taught and reported incorporation of MIT in Action Pack textbooks.

\subsection{Teachers' Age and Their Perceived Knowledge and Incorporation of MIT}

Table 8 presents the results of the association analysis between teachers' age and perceived knowledge and incorporation of MIT.

Table 8 shows that more teachers younger than 30 years reported hearing about MIT than both teachers 40 years or older and those between 30 and 40 years of age. It further shows that more teachers 40 years or older reported hearing about MIT than their 30-40-year-old counterparts.

Songs/video clips, board games, cooperative learning activities, videos/movies, listening, playing musical/ rhythmic instruments, jogging, body language, talking about (practicing) sports, visual aids (flashcards, pictures, wall charts, etc.) and classifying and categorizing activities were reportedly used more by 30-40-year-old teachers than their 40 or above and under 30-year-old counterparts, respectively, whereas drawing, group work, hands-on activities, logic puzzles and games and moving around the class were reportedly more used by 40 or above teachers than their 30-40- and under 30-year-old counterparts, respectively. By the same token, talking about mankind and related issues, coloring and speaking were reportedly used more by 30-40-year-old teachers than by their under 30 and 40 -year-old and above counterparts, respectively. 
Table 7. Results of $\chi^{2}$ test of independence regarding grade taught.

\begin{tabular}{|c|c|c|c|}
\hline Grade Crossing Question & $\chi^{2}$ Tests Value & $D_{f}$ & Sig. \\
\hline Have you ever heard about Multiple Intelligences Theory (MIT)? & 33.739 & 6 & 0.000 \\
\hline Have you ever researched about MIT? & 1.512 & 3 & 0.680 \\
\hline Would you like to know more about MIT? & 9.202 & 6 & 0.163 \\
\hline Do you think you use MIT in your teaching? & 4.436 & 6 & 0.618 \\
\hline Categorizing items (animals, adjectives, nouns, etc.) & 1.487 & 3 & 0.685 \\
\hline Reflective journal & 13.979 & 3 & 0.003 \\
\hline Group problem solving & 0.249 & 3 & 0.969 \\
\hline Pair work & 22.661 & 3 & 0.000 \\
\hline Songs/video clips & 8.183 & 3 & 0.042 \\
\hline Role plays & 14.874 & 3 & 0.002 \\
\hline Board games & 5.083 & 3 & 0.166 \\
\hline TPR/mime & 5.109 & 3 & 0.164 \\
\hline Cooperative learning activities & 5.310 & 3 & 0.150 \\
\hline Field trips (zoo, museums, restaurants, etc.) & 7.068 & 3 & 0.070 \\
\hline Debates & 30.228 & 3 & 0.000 \\
\hline Videos/movies & 2.086 & 3 & 0.555 \\
\hline Individualized projects & 16.109 & 3 & 0.001 \\
\hline Note-taking & 7.291 & 3 & 0.063 \\
\hline Drawing & 17.243 & 3 & 0.001 \\
\hline Listening & 9.536 & 3 & 0.023 \\
\hline Playing musical/Rhythmic instruments & 15.780 & 3 & 0.001 \\
\hline Making sculptures or art craft with clay, wood, or other materials & 26.444 & 3 & 0.000 \\
\hline Reading & 3.899 & 3 & 0.273 \\
\hline Maps & 7.221 & 3 & 0.065 \\
\hline Talking about mankind and related issues & 3.896 & 3 & 0.273 \\
\hline Coloring & 42.365 & 3 & 0.000 \\
\hline Speaking & 3.145 & 3 & 0.370 \\
\hline Personal journal keeping & 4.450 & 3 & 0.217 \\
\hline Talking about environmental issues & 11.724 & 3 & 0.008 \\
\hline Activities with a self-evaluation component & 5.390 & 3 & 0.145 \\
\hline Jazz chants/rhymes & 20.797 & 3 & 0.000 \\
\hline Singing & 33.113 & 3 & 0.000 \\
\hline Charts/grids & 8.097 & 3 & 0.044 \\
\hline Dancing & 18.606 & 3 & 0.000 \\
\hline Group work & 15.155 & 3 & 0.002 \\
\hline Jogging & 23.694 & 3 & 0.000 \\
\hline Body language & 6.573 & 3 & 0.087 \\
\hline Story telling & 18.615 & 3 & 0.000 \\
\hline Statistics & 9.405 & 3 & 0.024 \\
\hline
\end{tabular}




\begin{tabular}{cccc} 
Continued & & & \\
\hline Group brainstorming & 8.991 & 3 & 0.029 \\
Talking about (practicing) sports & 24.343 & 3 & 0.000 \\
Hands-on activities & 18.331 & 3 & 0.000 \\
Options for homework & 0.200 & 3 & 0.978 \\
Writing & 12.219 & 3 & 0.007 \\
Crossword puzzles & 7.819 & 3 & 0.050 \\
Logic puzzles and games & 3.809 & 3 & 0.283 \\
Moving around the class & 9.470 & 3 & 0.024 \\
Slides & 4.858 & 3 & 0.182 \\
Visual aids (flashcards, pictures, wall charts, etc.) & 11.730 & 3 & 0.008 \\
Story problems with numbers & 5.613 & 3 & 0.132 \\
Peer teaching & 16.279 & 3 & 0.001 \\
Classifying and categorizing activities & 1.661 & 3 & 0.646 \\
Talking about philosophical issues & 5.120 & 3 & 0.163 \\
Providing materials related to the natural world & 6.331 & 3 & 0.097 \\
\hline Do you think action pack textbooks incorporate MI activities? & 5.475 & 3 & 0.140 \\
\hline
\end{tabular}

Table 8. $\chi^{2}$ test of independence regarding teachers' age.

\begin{tabular}{cccc}
\hline Age Crossing Question & $\chi^{2}$ Tests Value & $D_{f}$ & Sig. \\
\hline Have you ever heard about Multiple Intelligences Theory (MIT)? & 15.939 & 4 & 0.003 \\
Have you ever researched about MIT? & 1.828 & 2 & 0.401 \\
Would you like to know more about MIT? & 6.526 & 4 & 0.163 \\
Do you think you use MIT in your teaching? & 5.166 & 4 & 0.271 \\
Categorizing items (animals, adjectives, nouns, etc.) & 4.708 & 2 & 0.095 \\
Reflective journal & 3.374 & 2 & 0.185 \\
Group problem solving & 5.816 & 2 & 0.055 \\
Pair work & 2.435 & 2 & 0.296 \\
Songs/video clips & 16.935 & 2 & 0.000 \\
Role plays & 0.475 & 2 & 0.789 \\
Board games & 6.264 & 2 & 0.044 \\
TPR/mime & 5.001 & 2 & 0.082 \\
Dideos/movies & 28.810 & 2 & 0.000 \\
Individualized projects & & 2 & 0.303 \\
Note-taking & 2.387 & 2 & 0.207 \\
Dield trips (zoo, museums, restaurants, etc.) & 3.154 & 2 & 0.007 \\
Debates & 9.799 & 2 & 0.681 \\
Drawing & 0.767 & 2 & 0.0245 \\
\hline
\end{tabular}




\section{Continued}

\begin{tabular}{|c|c|c|c|}
\hline Listening & 8.400 & 2 & 0.015 \\
\hline Playing musical/Rhythmic instruments & 8.093 & 2 & 0.017 \\
\hline Making sculptures or art craft with clay, wood, or other materials & 0.632 & 2 & 0.729 \\
\hline Reading & 0.299 & 2 & 0.861 \\
\hline Maps & 1.260 & 2 & 0.533 \\
\hline Talking about mankind and related issues & 8.320 & 2 & 0.016 \\
\hline Coloring & 12.701 & 2 & 0.002 \\
\hline Speaking & 7.605 & 2 & 0.022 \\
\hline Personal journal keeping & 5.764 & 2 & 0.056 \\
\hline Talking about environmental issues & 5.888 & 2 & 0.053 \\
\hline Activities with a self-evaluation component & 1.962 & 2 & 0.375 \\
\hline Jazz chants/rhymes & 3.918 & 2 & 0.141 \\
\hline Singing & 3.161 & 2 & 0.206 \\
\hline Charts/grids & 5.031 & 2 & 0.081 \\
\hline Dancing & 1.855 & 2 & 0.396 \\
\hline Group work & 7.763 & 2 & 0.021 \\
\hline Jogging & 6.223 & 2 & 0.045 \\
\hline Body language & 6.615 & 2 & 0.037 \\
\hline Story telling & 1.374 & 2 & 0.503 \\
\hline Statistics & 2.662 & 2 & 0.264 \\
\hline Group brainstorming & 2.417 & 2 & 0.299 \\
\hline Talking about (practicing) sports & 10.789 & 2 & 0.005 \\
\hline Hands-on activities & 9.983 & 2 & 0.007 \\
\hline Options for homework & 4.208 & 2 & 0.122 \\
\hline Writing & 1.143 & 2 & 0.565 \\
\hline Crossword puzzles & 3.086 & 2 & 0.214 \\
\hline Visual aids (flashcards, pictures, wall charts, etc.) & 12.559 & 2 & 0.002 \\
\hline Logic puzzles and games & 8.400 & 2 & 0.015 \\
\hline Moving around the class & 16.477 & 2 & 0.000 \\
\hline Slides & 2.439 & 2 & 0.295 \\
\hline Story problems with numbers & 2.664 & 2 & 0.264 \\
\hline Peer teaching & 2.397 & 2 & 0.302 \\
\hline Classifying and categorizing activities & 10.273 & 2 & 0.006 \\
\hline Talking about philosophical issues & 0.083 & 2 & 0.959 \\
\hline Providing materials related to the natural world & 3.456 & 2 & 0.178 \\
\hline Do you think Action Pack textbooks incorporate MI activities? & 1.767 & 2 & 0.413 \\
\hline
\end{tabular}


Teachers of the various age groups believed that Action Pack textbooks incorporate MIT in their activities, since no significant association was found between the grade taught and the perceived incorporation of MIT in Action Pack textbooks.

\subsection{Teachers' Qualification and Their Perceived Knowledge and Incorporation of MIT}

Table 9 presents the results of the association analysis between the teachers' qualification and their responses to the items of the questionnaire.

Table 9 shows that teachers with a Masters' or a Doctorate reportedly heard about MIT, researched it, want to know more about it, and use it in their teaching more than their counterparts who have a two-year diploma or a Bachelor's degree.

Group problem solving, debates, talking about environmental issues, body language, group brainstorming, peer teaching and talking about philosophical issues were reportedly used more by teachers with Masters' and Doctorate than those with Bachelor's and two-year diploma degrees, respectively, whereas songs/video clips, board games, drawing, coloring, singing, writing, visual aids (flashcards, pictures, wall charts, etc.) and story problems with numbers were reportedly used more by teachers with two-year diplomas, Bachelor's, and Masters' than those with Doctorate degrees, respectively.

Furthermore, TPR/mime, note-taking and slides were reportedly used more by teachers with two-year diplomas, Masters' and Doctorate degrees than those with a Bachelor's degree, respectively, while group work, options for homework, logic puzzles and games and classifying and categorizing were reportedly used more by teachers with a Bachelor's degree than their counterparts with Masters' and Doctorate degrees and two-year diplomas, respectively.

Table 9. $\chi^{2}$ test of independence regarding teachers' qualification.

\begin{tabular}{|c|c|c|c|}
\hline Qualification Crossing Question & $\chi^{2}$ Tests Value & $D_{f}$ & Sig. \\
\hline Have you ever heard about the Multiple Intelligences Theory (MIT)? & 37.175 & 4 & 0.000 \\
\hline Have you ever researched about MIT? & 20.806 & 2 & 0.000 \\
\hline Would you like to know more about MIT? & 16.031 & 4 & 0.003 \\
\hline Do you think you use MIT in your teaching? & 23.954 & 4 & 0.000 \\
\hline Categorizing items (animals, adjectives, nouns, etc.) & 4.932 & 2 & 0.085 \\
\hline Reflective journal & 4.996 & 2 & 0.082 \\
\hline Group problem solving & 11.612 & 2 & 0.003 \\
\hline Pair work & 4.316 & 2 & 0.116 \\
\hline Songs/video clips & 7.858 & 2 & 0.020 \\
\hline Role plays & 3.654 & 2 & 0.161 \\
\hline Board games & 14.128 & 2 & 0.001 \\
\hline $\mathrm{TPR} / \mathrm{mime}$ & 14.083 & 2 & 0.001 \\
\hline Cooperative learning activities & 2.108 & 2 & 0.349 \\
\hline Field trips (zoo, museums, restaurants, etc.) & 1.650 & 2 & 0.438 \\
\hline Debates & 11.646 & 2 & 0.003 \\
\hline Videos/movies & 2.105 & 2 & 0.349 \\
\hline Individualized projects & 0.070 & 2 & 0.966 \\
\hline Note-taking & 16.480 & 2 & 0.000 \\
\hline Drawing & 15.429 & 2 & 0.000 \\
\hline
\end{tabular}




\section{Continued}

\begin{tabular}{|c|c|c|c|}
\hline Listening & 1.620 & 2 & 0.445 \\
\hline Playing musical/Rhythmic instruments & 2.077 & 2 & 0.354 \\
\hline Making sculptures or art craft with clay, wood, or other materials & 2.759 & 2 & 0.252 \\
\hline Reading & 4.034 & 2 & 0.133 \\
\hline Maps & 3.807 & 2 & 0.149 \\
\hline Talking about mankind and related issues & 0.678 & 2 & 0.713 \\
\hline Coloring & 12.244 & 2 & 0.002 \\
\hline Speaking & 2.258 & 2 & 0.323 \\
\hline Personal journal keeping & 2.702 & 2 & 0.259 \\
\hline Talking about environmental issues & 11.635 & 2 & 0.003 \\
\hline Activities with a self-evaluation component & 0.264 & 2 & 0.876 \\
\hline Jazz chants/rhymes & 2.710 & 2 & 0.258 \\
\hline Singing & 22.393 & 2 & 0.000 \\
\hline Charts/grids & 0.701 & 2 & 0.704 \\
\hline Dancing & 4.319 & 2 & 0.115 \\
\hline Group work & 14.685 & 2 & 0.001 \\
\hline Jogging & 3.403 & 2 & 0.182 \\
\hline Body language & 6.887 & 2 & 0.032 \\
\hline Story telling & 0.949 & 2 & 0.622 \\
\hline Statistics & 0.215 & 2 & 0.898 \\
\hline Group brainstorming & 7.451 & 2 & 0.024 \\
\hline Talking about (practicing) sports & 1.120 & 2 & 0.571 \\
\hline Hands-on activities & 3.540 & 2 & 0.170 \\
\hline Options for homework & 13.778 & 2 & 0.001 \\
\hline Writing & 11.236 & 2 & 0.004 \\
\hline Crossword puzzles & 0.766 & 2 & 0.682 \\
\hline Visual aids (flashcards, pictures, wall charts, etc.) & 7.576 & 2 & 0.023 \\
\hline Logic puzzles and games & 7.789 & 2 & 0.020 \\
\hline Moving around the class & 0.260 & 2 & 0.878 \\
\hline Slides & 14.068 & 2 & 0.001 \\
\hline Story problems with numbers & 6.182 & 2 & 0.045 \\
\hline Peer teaching & 12.361 & 2 & 0.002 \\
\hline Classifying and categorizing activities & 9.301 & 2 & 0.010 \\
\hline Talking about philosophical issues & 9.612 & 2 & 0.008 \\
\hline Providing materials related to the natural world & 0.424 & 2 & 0.809 \\
\hline Do you think the Action Pack textbooks incorporate MI activities? & 1.477 & 2 & 0.478 \\
\hline
\end{tabular}


In short, teachers from various qualification levels perceived Action Pack textbooks to incorporate MIT in their activities, since no significant association was found between qualification and teachers' knowledge and perception of MIT incorporation in Action Pack textbooks.

\subsection{Teachers' Experience and Their Perceived Knowledge and Incorporation of MIT}

Table 10 presents the results of the association analysis between teaching experience and teachers' perceived knowledge and incorporation of MIT.

Table 10 shows that teachers with moderate experience (viz., 6 - 15 years) expressed willingness to know more about MIT than teachers with little (viz., $\leq 6$ years) or extensive (viz., >15 years) experience. On the other hand, teachers with extensive experience reportedly use MIT in their instruction more than their counterparts with little or moderate experience.

Teachers reportedly use MIT-based activities. Group problem solving, songs/video clips, cooperative learning activities, debates, drawing, playing musical/rhythmic instruments, making sculptures or art craft with clay, wood, or other materials, coloring, speaking, jazz chants/rhymes, singing, charts/grids, dancing, jogging, handson by activities and logic puzzles and games were reportedly used more by teachers with moderate experience than their counterparts with extensive or little experience as were videos/movies, maps, options for homework, crossword puzzles, visual aids (flashcards, pictures, wall charts, etc.), moving around class and classifying and categorizing activities. By contrast, note-taking, listening and group brainstorming were reportedly more used by teachers with little experience than their counterparts with extensive or moderate experience.

To reiterate, teachers from various experience levels perceived Action Pack textbooks to incorporate MIT in their activities, since no significant association was found between experience and perceived incorporation of

Table 10. $\chi^{2}$ test of independence regarding teachers’ experience.

\begin{tabular}{|c|c|c|c|}
\hline Experience Crossing Questions & $\mathrm{X}^{2}$ Tests Value & $D_{f}$ & Sig. \\
\hline Have you ever heard about the Multiple Intelligences Theory (MIT)? & 6.067 & 4 & 0.194 \\
\hline Have you ever researched about MIT? & 1.030 & 2 & 0.598 \\
\hline Would you like to know more about MIT? & 13.797 & 4 & 0.008 \\
\hline Do you think you use MIT in your teaching? & 13.108 & 4 & 0.011 \\
\hline Categorizing items (animals, adjectives, nouns, etc.) & 1.358 & 2 & 0.507 \\
\hline Reflective journal & 2.827 & 2 & 0.243 \\
\hline Group problem solving & 8.639 & 2 & 0.013 \\
\hline Pair work & 2.255 & 2 & 0.324 \\
\hline Songs/video clips & 9.511 & 2 & 0.009 \\
\hline Role plays & 4.397 & 2 & 0.111 \\
\hline Board games & 3.644 & 2 & 0.162 \\
\hline TPR/mime & 5.274 & 2 & 0.072 \\
\hline Cooperative learning activities & 35.991 & 2 & 0.000 \\
\hline Field trips (zoo, museums, restaurants, etc.) & 3.670 & 2 & 0.160 \\
\hline Debates & 7.280 & 2 & 0.026 \\
\hline Videos/movies & 7.330 & 2 & 0.026 \\
\hline Individualized projects & 3.362 & 2 & 0.186 \\
\hline Note-taking & 7.107 & 2 & 0.029 \\
\hline Drawing & 19.746 & 2 & 0.000 \\
\hline
\end{tabular}




\section{Continued}

\begin{tabular}{|c|c|c|c|}
\hline Listening & 6.888 & 2 & 0.032 \\
\hline Playing musical/Rhythmic instruments & 6.087 & 2 & 0.048 \\
\hline Making sculptures or art craft with clay, wood, or other materials & 17.786 & 2 & 0.000 \\
\hline Reading & 2.961 & 2 & 0.228 \\
\hline Maps & 7.797 & 2 & 0.020 \\
\hline Talking about mankind and related issues & 1.651 & 2 & 0.438 \\
\hline Coloring & 25.668 & 2 & 0.000 \\
\hline Speaking & 6.662 & 2 & 0.036 \\
\hline Personal journal keeping & 5.582 & 2 & 0.061 \\
\hline Talking about environmental issues & 1.851 & 2 & 0.396 \\
\hline Activities with a self-evaluation component & 5.868 & 2 & 0.053 \\
\hline Jazz chants/rhymes & 21.288 & 2 & 0.000 \\
\hline Singing & 20.829 & 2 & 0.000 \\
\hline Charts/grids & 8.866 & 2 & 0.012 \\
\hline Dancing & 9.179 & 2 & 0.010 \\
\hline Group work & 3.975 & 2 & 0.137 \\
\hline Jogging & 10.653 & 2 & 0.005 \\
\hline Body language & 5.517 & 2 & 0.063 \\
\hline Story telling & 0.309 & 2 & 0.857 \\
\hline Statistics & 0.118 & 2 & 0.943 \\
\hline Group brainstorming & 12.574 & 2 & 0.002 \\
\hline Talking about (practicing) sports & 1.237 & 2 & 0.539 \\
\hline Hands-on activities & 24.561 & 2 & 0.000 \\
\hline Options for homework & 11.231 & 2 & 0.004 \\
\hline Writing & 0.579 & 2 & 0.749 \\
\hline Crossword puzzles & 14.834 & 2 & 0.001 \\
\hline Visual aids (flashcards, pictures, wall charts, etc.) & 10.821 & 2 & 0.004 \\
\hline Logic puzzles and games & 9.964 & 2 & 0.007 \\
\hline Moving around the class & 19.053 & 2 & 0.000 \\
\hline Slides & 1.300 & 2 & 0.522 \\
\hline Story problems with numbers & 2.607 & 2 & 0.272 \\
\hline Peer teaching & 4.884 & 2 & 0.087 \\
\hline Classifying and categorizing activities & 13.091 & 2 & 0.001 \\
\hline Talking about philosophical issues & 1.276 & 2 & 0.528 \\
\hline Providing materials related to the natural world & 1.103 & 2 & 0.576 \\
\hline Do you think Action Pack textbooks incorporate MI activities? & 2.672 & 2 & 0.263 \\
\hline
\end{tabular}


MIT in Action Pack textbooks.

\subsection{Teachers' Participation in Training and Their Perceived Knowledge and Incorporation of MIT}

Table 11 presents the results of the association analysis between the teachers' participation in training programs and their perceived knowledge and incorporation of MIT.

Table 11 shows that teachers who participated in training programs reported having heard about, having researched, wanting to know more about and using MIT in their teaching than teachers who did not participate in training programs.

As for the use of MIT-oriented activities, debates, talking about environmental issues and options for homework were reportedly more used by the teachers who participated in training programs than those who while role plays and storytelling were reportedly used more by the teachers who did not participate in training programs than those who did. In short, teachers, who did or did not participate in training programs, perceived Action Pack textbooks to incorporate MIT in their activities, since no significant relationship was found between participation in training programs and perceptions of MIT-incorporation in Action Pack textbooks.

\section{Conclusions, Pedagogical Implications, Recommendations and Limitations}

To summarize, for the most part, the findings reveal that teachers reported both awareness and incorporation of MIT in their teaching, even though more so for male teachers than their female counterparts, which could be attributed to self-study or access to other resources. Furthermore, having such knowledge encouraged them to use MIT-based activities in their instruction. The findings also reveal that fourth-, eighth- and eleventh-grade teachers and those who are younger than 30 and 40 years or above reported hearing about MIT as did teachers with

Table 11. $\chi^{2}$ test of independence regarding teachers' training.

\begin{tabular}{|c|c|c|c|}
\hline Training Crossing Questions & $\mathrm{X}^{2}$ Tests Value & $D_{f}$ & Sig. \\
\hline Have you ever researched about MIT? & 4.390 & 1 & 0.036 \\
\hline Would you like to know more about MIT? & 8.764 & 2 & 0.013 \\
\hline Do you think you use MIT in your teaching? & 24.649 & 2 & 0.000 \\
\hline Categorizing items (animals, adjectives, nouns, etc.) & 0.243 & 1 & 0.622 \\
\hline Reflective journal & 0.666 & 1 & 0.415 \\
\hline Group problem solving & 2.146 & 1 & 0.143 \\
\hline Pair work & 0.091 & 1 & 0.762 \\
\hline Songs/video clips & 1.361 & 1 & 0.243 \\
\hline Role plays & 4.213 & 1 & 0.040 \\
\hline Board games & 2.128 & 1 & 0.145 \\
\hline TPR/mime & 3.669 & 1 & 0.055 \\
\hline Cooperative learning activities & 0.516 & 1 & 0.472 \\
\hline Field trips (zoo, museums, restaurants, etc.) & 1.525 & 1 & 0.217 \\
\hline Debates & 4.210 & 1 & 0.040 \\
\hline Videos/movies & 0.003 & 1 & 0.958 \\
\hline Individualized projects & 0.299 & 1 & 0.584 \\
\hline Note-taking & 0.653 & 1 & 0.419 \\
\hline Drawing & 1.726 & 1 & 0.189 \\
\hline
\end{tabular}




\section{Continued}

\begin{tabular}{|c|c|c|c|}
\hline Listening & 0.291 & 1 & 0.590 \\
\hline Playing musical/Rhythmic instruments & 0.208 & 1 & 0.649 \\
\hline Making sculptures or art craft with clay, wood, or other materials & 0.165 & 1 & 0.685 \\
\hline Reading & 0.693 & 1 & 0.405 \\
\hline Maps & 0.770 & 1 & 0.380 \\
\hline Talking about mankind and related issues & 1.083 & 1 & 0.298 \\
\hline Coloring & 0.019 & 1 & 0.890 \\
\hline Speaking & 0.956 & 1 & 0.328 \\
\hline Personal journal keeping & 2.460 & 1 & 0.117 \\
\hline Talking about environmental issues & 3.985 & 1 & 0.046 \\
\hline Activities with a self-evaluation component & 0.024 & 1 & 0.877 \\
\hline Jazz chants/rhymes & 0.000 & 1 & 0.985 \\
\hline Singing & 0.299 & 1 & 0.584 \\
\hline Charts/grids & 0.094 & 1 & 0.759 \\
\hline Dancing & 0.954 & 1 & 0.329 \\
\hline Group work & 0.027 & 1 & 0.868 \\
\hline Jogging & 0.534 & 1 & 0.465 \\
\hline Body language & 1.941 & 1 & 0.164 \\
\hline Story telling & 10.257 & 1 & 0.001 \\
\hline Statistics & 0.075 & 1 & 0.784 \\
\hline Group brainstorming & 7.310 & 1 & 0.007 \\
\hline Talking about (practicing) sports & 1.517 & 1 & 0.218 \\
\hline Hands-on activities & 0.169 & 1 & 0.681 \\
\hline Options for homework & 5.045 & 1 & 0.025 \\
\hline Writing & 1.602 & 1 & 0.206 \\
\hline Crossword puzzles & 0.028 & 1 & 0.867 \\
\hline Visual aids (flashcards, pictures, wall charts, etc.) & 0.833 & 1 & 0.362 \\
\hline Logic puzzles and games & 2.436 & 1 & 0.119 \\
\hline Moving around the class & 0.325 & 1 & 0.569 \\
\hline Slides & 1.327 & 1 & 0.249 \\
\hline Story problems with numbers & 0.192 & 1 & 0.661 \\
\hline Peer teaching & 0.000 & 1 & 0.995 \\
\hline Classifying and categorizing activities & 0.347 & 1 & 0.556 \\
\hline Talking about philosophical issues & 0.355 & 1 & 0.551 \\
\hline Providing materials related to the natural world & 0.033 & 1 & 0.855 \\
\hline Do you think the Action Pack textbooks incorporate MI activities? & 3.761 & 1 & 0.052 \\
\hline
\end{tabular}


Masters' or Doctorate degrees and those who participated in training programs.

MIT-incorporation in Action Pack textbooks was positively perceived by teachers across the variables of the study, which may indicate that the textbook series under study incorporates different types of MIT-oriented activities. As mentioned earlier, the abundance of MIT-related activities may have resulted from the CLT-orientation of the textbooks under study, which is consistent with previous research findings (cf., for example, [33]) that the variety of materials encouraged in CLT promote communicative language use and, thus, foster multiple intelligences. When MIT is implemented, a minimum of eight different pathways to learning are available to students, which not only facilitates learning but also makes it more enjoyable. MIT further allows teachers to be conscious of their teaching strategies and students' abilities and strengths which, in turn, allows them to better present the curriculum.

To help EFL teachers know about and implement new innovative methods in foreign language teaching, the Jordanian MoE is called upon to organize more workshops and training programs. Conference participation may also be a good opportunity for teachers to exchange experiences with fellow practitioners. The MoE may also make use of its vast electronic capabilities to disseminate materials (e.g., a newsletter) to EFL and other teachers promoting educational innovations and viable teaching and learning practices.

In conclusion, within the limitations of this study, it appears that if attempts at educational reform are to be successful, future research efforts should focus on the facilitative effect of teachers' beliefs prior to planning classes, workshops or seminars. Failure to do so may prove counter-productive in terms of time and funding.

With the rapid educational innovations, made better and more accessible by technology, this is an ideal time for advances in MI-related instructional delivery to meet the ever-growing spectrum of learners. By using MIT, ESL teachers can adopt multiple modalities to develop not only their students' linguistic abilities but also these students' cognitive, social and emotional abilities.

These researchers are aware of the fact that self-reported data, not backed by classroom observation, may reflect preferred rather than actual classroom practice [35]. Thus, more research that triangulates by combining survey, classroom observation and case studies, among other techniques, is in order to carry these findings along and add more rigorous generalizable data about the relationship between teachers' awareness, beliefs and perceptions about instructional innovations and their classroom use of these innovations.

This research examined potential relationships among gender, age, qualifications, years of experience, grade level and participation in training programs, but other variables, including teachers' knowledge (both of subject matter and pedagogy), school type and resources (public vs. private; primary vs. secondary; rural vs. urban) as well as teachers' beliefs, may be readily investigated. One aspect that these researchers find worth researching, following from the current findings, is whether or not school context could affect teachers' pedagogical practices even among teachers with similar self-reported awareness or beliefs about MIT.

\section{References}

[1] Levitt, K.E. (2002) An Analysis of Elementary Teachers’ Beliefs Regarding the Teaching and Learning of Science. Science Education, 86, 1-22. http://dx.doi.org/10.1002/sce.1042

[2] Bataineh, R.F., Bataineh, R.F. and Thabet, S.S. (2011) EFL Teachers' Knowledge of and Classroom Subscription to Communicative Language Teaching: Embraced or Lip-Serviced? Journal of Language Teaching and Research, 2, 859866.

[3] Beck, J., Czerniak, C. and Lumpe, A. (2000) An Exploratory Study of Teachers’ Belief Regarding the Implementation of Constructivism in their Classrooms. Journal of Science Teacher Education, 11, 323-343. http://dx.doi.org/10.1023/A:1009481115135

[4] Haney, J. and McArthur, J. (2002) Four Case Studies of Prospective Science Teachers' Beliefs Concerning Constructivist Teaching Practices. Science Education, 86, 783-802. http://dx.doi.org/10.1002/sce.10038

[5] Pajares, F. (1992) Teachers’ Beliefs and Educational Research: Cleaning up a Messy Construct. Review of Educational Research, 62, 307-332. http://dx.doi.org/10.3102/00346543062003307

[6] Roehrig, G. and Kruse, R. (2005) The Role of Teachers’ Beliefs and Knowledge in the Adoption of a Reform-Based Curriculum. School Science and Mathematics, 105, 412-422. http://dx.doi.org/10.1111/j.1949-8594.2005.tb18061.x

[7] Williams, M. and Burden, R. (1997) Psychology for Language Teachers: A Social Constructivist Approach. Cambridge University Press, Cambridge.

[8] Kampylis, P. (2010) Fostering Creative Thinking: The Role of Primary Teachers. Jyväskylä Studies in Computing, 115, 
171 p. https://jyx.jyu.fi/dspace/bitstream/handle/123456789/24835/Kampylis_Panagiotis_screen.pdf?sequence=2

[9] Bataineh, R.F., Al Omari, T.M. and Smadi, O.M. (Forthcoming) The Inclusion of Multiple Intelligences in Jordanian EFL Textbooks: A Content Analysis. International Journal of Applied Educational Studies.

[10] Bocconi, S. and Trentin, G. (2012) Wikis Supporting Formal and Informal Learning. Nova Science Publishers, New York.

[11] Redecker, C., Ala-Mutka, K., Bacigalupo, M., Ferrari, A. and Punie, Y. (2009) Learning 2.0: The Impact of Web 2.0 Innovations on Education and Training in Europe. Final Report (No. EUR 24103EN), European Commission-Joint Research Center -Institute for Prospective Technological Studies, Seville. http://ipts.jrc.ec.europa.eu/publications/pub.cfm?id=2899

[12] Rogers, T. (2003) Methodology in the Millennium. English Teaching Forum, 41, 2-13. http://americanenglish.state.gov/files/ae/resource_files/03-41-4-a.pdf

[13] Armstrong, T. (2000) Multiple Intelligences in the Classroom. 2nd Edition, Association for Supervision and Curriculum Development, Alexandria.

[14] Kallenbach, S. and Viens, J. (2002) Open to Interpretation: Multiple Intelligences Theory in Adult Literacy Education. NCSALL Report 21. National Center for the Study of Adult Learning and Literacy, Harvard Graduate School of Education, Cambridge.

[15] Gardner, H. (1983/2004) Frames of Mind: The Theory of Multiple Intelligences. 1st/10th Edition, Basic Books, New York.

[16] Berman, M. (2005) A Multiple Intelligences Road to ELT Classroom. Cromwell Press, Trowbridge.

[17] Anderson, R. and Helms, J. (2001) The Ideal of Standards and the Reality of Schools: Needed Research. Journal of Research in Science Teaching, 38, 3-16. http://dx.doi.org/10.1002/1098-2736(200101)38:1<3::AID-TEA2>3.0.CO;2-V

[18] Haney, J., Czerniak, C. and Lumpe, A. (1996) Teacher Beliefs and Intentions Regarding the Implementation of Science Education Reform Strands. Journal of Research in Science Teaching, 33, 971-993. http://dx.doi.org/10.1002/(SICI)1098-2736(199611)33:9<971::AID-TEA2>3.0.CO;2-S

[19] Nespor, J. (1987) The Role of Beliefs in the Practice of Teaching. Journal of Curriculum Studies, 19, 317-328. http://dx.doi.org/10.1080/0022027870190403

[20] Huberman, M. (1993) The Lives of Teachers. Teachers College Press, New York.

[21] Christison, M. (1998) Applying Multiple Intelligences Theory in Pre-Service and In-Service TEFL Education Programs. English Teaching Forum, 36, 3-13.

[22] Richards, J. and Rodgers, T. (2001) Approaches and Methods in Language Teaching. Cambridge University Press, Cambridge. http://dx.doi.org/10.1017/CBO9780511667305

[23] NCSALL (2006) Adult Multiple Intelligences Theory. Harvard University Graduate School Education. http://www.ncsall.net/fileadmin/resources/teach/ami_theory.pdf

[24] Gardner, H. (2003) Multiple Intelligences after Twenty Years. http://www.pz.harvard.edu/PIs/HG MI after 20 years.pdf

[25] Gilman, L. (2001) Human Intelligence: The Theory of Multiple Intelligences. http://www.indiana.edu/ intell/mitheory.shtml

[26] Smith, M. (2008) Howard Gardner, Multiple Intelligences and Education. http://www.infed.org/thinkers/gardner.htm

[27] Weiss, S. (1999) Extra! Extra! Interview with Howard Gardner. NEA Today Online. http://www.nea.org/neatoday/9903/gardner.html

[28] Moran, M., Kornhaber, M. and Gardner, H. (2006) Orchestrating Multiple Intelligences. Educational Leadership, 64. http://www.learnersedgeinc.com/file/716Orchestrating\%20Multiple\%20Intelligences.pdf

[29] Giles, E., Pitre, S. and Womack, S. (2003) Multiple Intelligences and Learning Styles. In: Orey, M., Ed., Emerging Perspectives on Learning, Teaching and Technology. http:/projects.coe.uga.edu/epltt/

[30] Christison, M. and Kennedy, D. (2003) Multiple Intelligences: Theory and Practice in Adult ESL. Eric Digest. http://www.ericdigests.org/2001-1/multiple.html

[31] Arikan, A. and Saricaoğlu, A. (2009) A Study of Multiple Intelligences, Foreign Language Success and Some Selected Variables. Journal of Theory and Practice in Education, 5, 110-122.

[32] Şad, N. and Arıbaş, S. (2008) The Levels of Teachers at Primary Schools to Employ Materials and Activities Based on Multiple Intelligences Theory: Malatya Sample. Inönü Üniversitesi Eğitim Fakültesi Dergisi, 9, 169-187.

[33] Botelho, M. (2003) Multiple Intelligences Theory in English Language Teaching: An Analysis of Current Textbooks, Materials and Teachers’ Perceptions. Master's Thesis. http://www.ohiolink.edu/etd/sendpdf.cgi?ohioul079466683 
[34] Ministry of Education (2006) General Guidelines and General and Specific Outcomes for the English Language. Basic and Secondary Stages. 1st Edition, Ministry of Education, Amman.

[35] Fang, Z. (1996) A Review of Research on Teacher Beliefs and Practices. Educational Research, 38, 47-65. http://dx.doi.org/10.1080/0013188960380104 